\title{
Testifying for the poor: Epistolary advocates and the negotiation of parochial relief in England, 1800-1834
}

The English and Welsh poor law of 1601 created the framework for a national welfare system in which care for the very poorest segments of society was to be delivered at the level of the Anglican parish, by elected officers and using the proceeds of a tax on local property to meet need. ${ }^{1}$ Despite recent assertions to the contrary, this was a discretionary welfare system. Those falling into poverty were enabled to apply for welfare payments in cash and kind, and even given an avenue of appeal if turned down, but no legal right to receive welfare and no legal obligation on parishes to provide it existed. ${ }^{2}$ At the heart of this discretionary system lay a set of tensions that we would recognise as essentially modern: Who should be eligible for welfare? How should the benefits associated with eligibility be set against accumulated contribution? How should private philanthropic activities relate to the state welfare system? What should officials and communities 'do' about in-migrants? How could the poor learn the rules for navigating a discretionary system? What was the accepted ground of contestability for the decisions of officials? And how malleable should the decision-making system of the local/parish state be in the face of these tensions? The so-called settlement laws of the $1660 \mathrm{~s}$ (variously amended thereafter) provided clarity on some of these issues. By birth, marriage, the paying of tax or the serving of an apprenticeship, all English and Welsh people obtained and might change a 'settlement'. Places of settlement were, in turn, the locus of applications for welfare and those drawn out of their place by migration at the time they fell into poverty, or threatened to fall into poverty, could be subject to elaborate, protracted and often expensive removal procedures involving repatriation to a settlement parish. ${ }^{3}$

In the case of those living in or removed to a settlement parish - the 'in-parish poor' our understanding of how this discretionary welfare system was experienced and navigated by paupers has become increasingly nuanced, particularly for the later decades of the Old Poor Law (1790-1834) when source material becomes particularly rich. For this group, older notions that parishes and their officials employed strict moral yardsticks for eligibility have been challenged by studies of parochial records and diaries demonstrating that officials, elites and ratepayers were often unwilling or unable to prevent relief being paid to the morally reprobate. Those turned down by officials or ratepayers (the latter in the forum of "the vestry") usually returned with similar claims to test the consistency of decision-making. Recent research from Steven King has suggested that paupers knew the law of welfare very 
well, while Peter King has shown persuasively that they frequently had formal and informal resort to magistrates in order to reaffirm their eligibility. ${ }^{4}$ These magistrates, many of whom were local and appear to have been broadly sympathetic to the poor, were both knowable and known to the 'in-parish poor'.

This said, resort to the law was on the muscular end of the spectrum of pauper responses to the vagaries of a discretionary welfare system. The minutes of vestry meetings show that in-parish paupers generally approached those supplying welfare with deference and a sophisticated sense of the landscape and language of negotiation. Yet, the same records also sometimes point to confrontation, anger and an ingrained frustration on the part of both paupers and ratepayers over ongoing claims. As Susannah Ottoway and others have pointed out, for the in-parish poor customary and Christian practice had created in many places a sense that certain groups (the sick, aged, impaired, children, etc.) should get relief, even if parochial authorities retained the power to make that relief inconsistent, low, contingent and highly variable across regions and types of community. ${ }^{6}$ Certainly, by the 1790 s it is clear that the in-parish poor expected parochial officials to negotiate rather than simply to impose relief. John Daniell, the joint overseer of Doncaster parish (South Yorkshire), was not unusual amongst overseers of the poor in referring to payments being made "according to agreement" with the pauper concerned. When considering the case of Ann Hill and her regular relief payments in October 1794 he wondered whether she "should not be taken into the House, she wanting further relief". After visiting, however, he "Agreed to give her 2s a week instead of 1s," suggestive of an act of face-to-face negotiation and definitive pauper agency. ${ }^{7}$ The terminology in this case is subtle but important and points to some of the mechanisms by which the in-parish poor might create fixed reference points in a discretionary system. An older literature which tensioned questions of whether Old Poor Law policies at the local level were driven primarily by expediency (the size of the tax base or a desire to ensure social stability) or by a genuinely communitarian set of precepts has given way to a sense of the pragmatism and fluidity of most welfare practice.

For both parishes and paupers, the question of the eligibility of migrants who were out of their place of settlement was potentially much more complex. The nature and frequency of migration meant that all English and Welsh communities would have had some people living "away" from their settlement parish at the time they fell into poverty. Equally, all places would have been host to migrants whose settlements, and thus the liability for relieving poverty where a case was accepted, were elsewhere. Rules which meant that women changed their settlement to that of their husband at marriage and that illegitimate children were given 
the settlement in the place they were born rather than that of their father or mother, further complicated the picture. Steven King has argued that in some communities the majority of claimants were comprised of the non-settled poor. ${ }^{8}$ Such observations probably apply to only a small minority of urban or de-industrialising areas, but the sense that the 'out-parish poor' constituted an important practical and ideological problem should not be lost.

In turn, it is now clear that the removal aspect of English and Welsh settlement laws was applied sparingly and sporadically. Even if they felt subject to surveillance or were keenly attuned to the threat of removal, in practice very few of those who could have been removed were sent back to their parish of settlement. ${ }^{9}$ Rather, parishes forged numerous bilateral agreements, either active or passive, through which they agreed to support "their" paupers in a host parish. This "out-parish relief system" might involve the yearly reckoning of relative liabilities or the ongoing transmission of money. Its dimensions and mechanics are becoming increasingly clear as historians focus their attentions on the experiential dynamics of the poor through the analysis of pauper letters. ${ }^{10}$ Such documents were written by or for the poor as part of the process of convincing settlement parishes to grant relief in a host (i.e. non-settlement) parish, and they have been regarded as a means of recovering an elusive, even authentic, "voice of the poor". 11 They are part of a wider stock of correspondence between parishes which collectively affords us a rich window onto the operation of the English and Welsh relief system, particularly in the later decades of the Old Poor Law.

Yet the question of how the out-parish poor in particular navigated a discretionary welfare system so as to establish entitlement and how parochial officials understood their role as recipients of communications remain as problematic as they are important. Lynn Hollen Lees suggests that "entitlement is a modern word that points to the terrain within which ... struggles over rights and obligations took place," and nowhere was such terrain rougher or the struggle more intense than when considering whether, where and how to distribute benefits to migrants. ${ }^{12}$ For the out-parish poor, distance from a settlement parish created an intervening layer of complexity that often did not apply to those who remained "at home". ${ }^{13}$ Local magistrates (that is, local to the "home" parish) were often distant both physically and conceptually from the out-parish poor. While the contribution of the in-parish poor (financial, material, social, cultural) to their communities could be witnessed or evidenced by neighbours and family, those living away necessarily found it harder to tie eligibility to contribution, or to provide evidence for it. Because they lived at a distance, almost all writers asked for relief in cash, whereas the in-parish poor could meld requests for relief in cash and kind so as to allay suspicions that they would fritter away their allowances; and the in-parish 
poor would have seen or heard of the impact of their claims first-hand. Their proximity arguably gave them a greater sensitivity to the contestability of welfare and simultaneously gave in-parish paupers the ability to readily offer more information or to call casually on local people to correct misapprehensions about reputation or circumstance.

It has thus often been assumed that for the out-parish pauper establishing entitlement must always have been a matter of anxiety and, to a greater or lesser extent, one of strategy, regardless of the ostensible strength of their case. ${ }^{14}$ Research into the claims and treatment of the sick poor suggest that this dichotomy between the knowledge and strategies of in- and out-parish paupers should perhaps not be so starkly drawn. ${ }^{15}$ Moreover, distance from a settlement parish did not necessarily mean that paupers were cut off from intelligence and news from their home parish. Indeed many letters emphasised how paupers had kept in touch with people "at home" via visits, letters, reading newspapers or meeting the carters and others who travelled between parishes and carried gossip as well as goods. Nonetheless, there is a clear sense from much of the literature on the experiential dynamics of the Old Poor Law that establishing and maintaining entitlement in a discretionary system was likely to be a particularly fraught process for migrants, much as it remains today.

Against this backdrop, those writing on the dual themes of the out-parish poor and their eligibility have concentrated solely or largely on the rhetorical and strategic agency of the poor themselves as revealed in their own letters. ${ }^{16}$ This is unsurprising. Letters which begin "Perhaps you may take me for a Lady of Fortune because some of my Friends got the Bishop of Durham to write to Mr Flamank about the payment of the Money. I must therefore undeceive you;" or which contain an observation like "and besides we have been three parts fameshed for want of Vituals being Seven in family and my Children have took the peelings out of the pigs wash and Eate them for Hunger," are intuitively interesting, potentially reveal much about the experiences of the poor, and speak to much wider themes of dignity, agency and the operation of labour markets. ${ }^{17}$ Yet, focusing on the full corpus of parochial correspondence by (or about) the poor - overseers' letters, pauper narratives, and the communications of advocates and professionals - reveals that the classic pauper letter was actually a minority form. ${ }^{18}$ This remains the case even if we acknowledge that many letters were sent but not retained, something that is clearly visible in vestry minutes where letters were read out to ratepayers but have not subsequently survived. Letters about the poor rather than $b y$ them were the dominant narrative form. Indeed, even where paupers wrote a series of letters to their settlement parish, a reassembling of the chronological run of that series usually reveals interspersing overseers' correspondence and letters from third parties. 
Yet, the role of official and unofficial advocates (parish officers, magistrates, landlords, doctors, employers, etc.) in helping the poor to navigate the English and Welsh welfare system has been completely neglected. ${ }^{19}$ This is unfortunate. Lynn Hollen Lees has argued that, under the Old Poor Law, "[w]hatever the motivations of the parties involved, the result of welfare transactions was unavoidably a reinforcement of social solidarity on the communal level". For her the poor law was defined and bounded by "the morris dance of interlocking obligation" between the have-nots in the relief process and those who, to whatever small degree, were in a position to help them establish a stronger case for assistance. ${ }^{20}$ If this was true, and true of face-to-face transactions over the vestry table or in the overseers' parlour, then it was even more so in the case of the official and unofficial advocates who dealt on behalf of the poor from a distance.

An investigation into the correspondence of epistolary advocates thus provides a vital corrective to the cumulative historiography on English and Welsh pauper letters. Such an analysis also provides a window onto how a substantial group of the poor sought to navigate a discretionary welfare system, and feeds into wider debates about the intent and sentiment of the Old Poor Law. Moreover, identifying key groups of epistolary advocates allows us to grapple with wider questions: about social obligations and reciprocity, the malleability of state power, the longevity of customary, Christian and philanthropic duty and, very importantly, the way that communities thought about the inclusion or exclusion of migrants. In this article, we thus focus on the writing of advocates for the poor during the closing decades of the Old Poor Law, a period often associated with dwindling sympathy for the claims of the poor in the political and (tax paying) public imagination. After a consideration of the scale and character of the corpus, we move on to review the role of a group of advocates we describe as 'friends' to the poor: respectable and well-to-do inhabitants who acted willingly and actively in a spirit of patronage in parish negotiations, and who, by so doing, helped to shape the nature of those negotiations. Following this, we offer a brief review of others who acted on the poor's behalf, including employers and landlords. The final, most substantial, section investigates parish officials and the nature of their representations on behalf of out-parish paupers. We argue that the parish state was, and was supposed to be, malleable in the face of the claims of epistolary advocates; that the words and strategies of such advocates provided important yardsticks to the poor in navigating a discretionary welfare system; and that the often passionate advocacy of the group, even of local officials themselves, points to a strong underlying commitment to the migrant poor 
which was not generally diluted at parochial level in the later Old Poor Law whatever the wider political narrative might indicate. ${ }^{21}$

\section{The Nature of Advocacy in Pauper Correspondence}

Peter Jones has described the way that paupers used the letter-writing process as a means of "[filtering] their material and practical needs through a fine rhetorical mesh," so that "such requests to a greater or lesser extent fulfilled, or corresponded to, the expectations and imperatives" of parish officers. ${ }^{22}$ Others, too, have noted that pauper letters were "strategic pieces of writing," designed to gain competitive advantage within the relief relationship. ${ }^{23}$ Yet to acknowledge that pauper letters were rhetorical in their construction and strategic in their intent is not to imply that they were documents intended to deceive. Indeed, parishes satisfied themselves of the veracity of out-parish paupers' claims through formal or informal surveillance methods which ranged from personal visits by the home overseer or another vestry member through to surveillance by proxy, using the agency of a trusted or nominated person from the host parish itself. Thomas Sokoll has even suggested for Essex that "if anything the surveillance of nonresident paupers must have been closer than that of those residing in their parishes," a clear indication of the thorny practical and ideological problems that migrants posed to parochial communities. ${ }^{24}$ Such surveillance notwithstanding, an outparish pauper's word was unlikely to have been enough, on its own, to establish entitlement. It is for this reason that those studying pauper letters have pointed persuasively to, inter-alia: instances where a writer actively invites surveillance; efforts on the part of paupers to construct a shared linguistic register with officials; the appearance of well understood yardsticks of deservingness - nakedness, starvation, etc. - in series of letters from the same person; and a tendency for paupers to appropriate the voices of others in the formulation: "Doctor X says...," or "My neighbours think...". Yet it is likely that by far the most persuasive indicator of truthfulness, need and deservingness would have been the word of a "trusted other" who could and would speak/write directly on the pauper's behalf.

The numerical importance of such advocates' correspondence is compelling. For the purposes of this study, a total of 1,100 letters to English parishes were analysed, all of which constitute appeals for relief either by, or on behalf of, paupers. The vast majority come from county archive collections, and they constitute all such letters which could be found in those collections. In common with other studies most of the letters cluster in the period between the 
$1790 \mathrm{~s}$ and $1830 \mathrm{~s}^{25}$ The counties represented were deliberately chosen because they represent significant typological contrasts and might reveal something about the regionality of poor law cultures. Early nineteenth-century Devon (186 letters) remained a relative rural backwater ${ }^{26}$; Surrey (287 letters), like Essex and Berkshire, was in socio-economic and cultural terms strongly orientated towards London and experienced significant in, out and throughmigration $^{27}$; early nineteenth-century Northamptonshire (299 letters) exhibited a complex mix of rapid industrialisation and simultaneous de-industrialisation, while strong urbanisation sat alongside the development of a credible commercial agricultural sector driven by the high penetration of great estates; West Yorkshire (293 letters), combined both subsistence agriculture and highly commercial arable and pastoral production and was above all an urban-industrial county demonstrating very significant population and industrial production growth rates by the early nineteenth century; and the City of Westminster (35 letters) provides a metropolitan perspective within a landscape of narratives where London is significantly under-represented because of sustained problems of source retention and survival.

Within this broad corpus, appeals made by advocates on behalf of paupers, or wouldbe paupers, constitute over half (671, or 61 per cent) of all the narratives. We have not, in calculating these figures, included instances where third parties were asked to simply add a postscript in support of a pauper narrative, something which is common throughout the sample. Our initial high level analysis of this sub-group of letters found little spatial or chronological variation in the intent, content, rhetoric or strategic approach of authors. The numerical presence of epistolary advocates in the overall cadre of correspondence did, however, vary between counties. Advocate letters constitute around 40 per cent of all appeals in Westminster and Devon, 46 per cent in Northamptonshire, 62 per cent in Surrey, and almost 70 per cent in West Yorkshire. This sort of distribution suggests no obvious coherent regional patterning, something confirmed by a control sample for Norfolk and Lancashire, where advocate letters constitute 44 per cent and 52 per cent respectively of the overall corpus. Nor do such distributions map cleanly onto the spatial patterning of poor law payments per capita, literacy rates, transport infrastructure or intensity of urbanisation. The individual county samples are small enough for the differences to be explained by random variation or local retention policies at the time or subsequently. On the other hand, the different complexions of the county samples feel both real and important. One potential explanation might be the duration or expected duration of welfare payments, with paupers in counties where such durations were generally short turning to advocates sooner than their 
counterparts in other counties where it was worth investing more time and energy in building a personal relief relationship. ${ }^{28}$ Alternatively, and perhaps more likely, this spatial patterning might reflect the strength and formality of the out-parish system and underlying interparochial relationships. Communities in Lancashire and Yorkshire, for instance, appear to have been much more likely to keep formal ledgers detailing their payment relationships with other parishes than those in the English midlands or south. Against such a backdrop, it would be unsurprising if officials in particular were not to play a more central role than in places where the attitude towards making and keeping inter-parochial relations was rather looser.

However we explain this distribution, it is clear that within an overall network of correspondence about/for an individual or family, advocates followed one or more strategies of instigation, interspersal, substitution or intervention. Instigating letters were those which made an initial approach to a settlement parish and which laid the foundations for a chain of correspondence that, at its richest, might involve paupers themselves, officials, family members and various advocates. A pattern of interspersal can be discerned where one or more advocates' letters appears arbitrarily in a sequence of correspondence. Such letters seem to have been contingent upon a pauper meeting an advocate unexpectedly, or the advocate simply responding to a rumour about the circumstances of the family concerned.

Interspersing letters rarely picked up threads from preceding items of correspondence or led to sustained follow-through in subsequent narratives. Indeed, several such letters might appear in a set of correspondence about a single pauper. A pattern of substitution involved an advocate taking up the narrative strands from the pauper concerned or from another advocate. This does not mean that paupers themselves stopped writing, but the narrative drive of the conversation with officials in a settlement parish switched in favour of the advocate. Finally, an intervening pattern involved epistolary advocates responding to a perceived, claimed or rhetoricised 'crisis' in the ongoing narrative of the pauper or their family. Such crises included, amongst others, distraint of goods for missed rent, nakedness, starvation or severe illness, and sometimes involved confrontation with officials especially where initially constructive letters went unheeded or unanswered.

Of course, a single set of correspondence could include multiple advocates following all four patterns. And at its most complex a single advocate letter encompassed multiple advocate voices. Thus, Reverend William Howarth wrote an intervening letter from March (Cambridgeshire) to Peterborough (Northamptonshire) on 15 April 1833 on the subject of Joseph Clark and his family to whom "My attention was this morning called". Pointing to unemployment and chronic sickness in the family, Howarth also appropriated the voice of 
"the medical gentleman who is kindly attending them" and who "thinks the womans life in great danger." Expressing the view that the family were "altogether in a most distressed and folorn condition," he further appropriated the voice of Clark's employer who "gives him an excellent character for steadiness and industry, but not belonging to our parish he has been unable during the winter to obtain any work, except and occasional job."29

We should not, however, let the most complex and layered examples deflect from the clear sense that advocates usually knew what was required of their narratives depending on the point at which they intervened. The fact that advocates were willing to take up the cause of the proximate poor in such numbers and across this typological spectrum might be taken as an indicator of the depth of individual philanthropy at parochial level. Such interventions can, after all, be constructed as essentially charitable acts. The sense that advocates clearly thought the officials receiving their letters ought to consider and act upon them also suggests a deeply ingrained expectation that the power of the local state was malleable and contingent. Unsurprisingly, then, there were some clear underlying features in the role of advocate. The most obvious, and certainly the most important, is that they fulfilled the broad Hanoverian requirement for "respectability". The vast majority of those who wrote on behalf of paupers were parish officials, ministers, surgeons and doctors, employers, and occasionally the minor Gentry. Clearly, there is little mystery in this. The poor wanted as advocates and sponsors those in the host community who would have been able to speak with authority on their behalf, and who would have expected to have been listened-to by overseers and vestry officials, even at a distance. Whether chosen by paupers or self-selecting, advocates wrote as equals and sometimes superiors to officials and taxpayers: in fulfilling their role as advocates they wrote, quite literally, to people just like themselves.

Almost all of the writers in the corpus were $\mathrm{male}^{30}$, and the advocate letters were written from, and related to, paupers in a broadly balanced urban and rural subset. While most letters asked officials for "relief" or "assistance," specific and quantified requests for clothing, rent, nursing and medical aid and food or fuel were also found. Reflecting the varying points at which advocates might enter a train of correspondence, significant numbers of letters requested the continuance of payments or the enhancement of existing relief levels. Despite these broad regularities, advocates were by no means a homogeneous group. Both the subtle purpose of the letters they wrote, and the manner in which they framed their rhetorical appeals, differed depending on their precise relationship with the pauper and parish officials concerned. It is to these issues that we now turn. 


\section{Typologies of Advocates' Letters}

For the purposes of this article we have divided our sample of advocates' letters into seven broad categories: parish officials (letters from whom constitute 36 per cent), 'friends' (35 per cent), medical men (just over 15 per cent), employers, landlords or creditors, and 'others' (just over 13 per cent combined). The first category - that of parish officials - is of particular importance in considering the key questions outlined in our introduction. This correspondence tells us more about the malleability of local welfare policy, the disputed position of migrants, the nature of inter-parish relations and the establishment of entitlement than any of the others and, arguably, more than any other single source in the parish archives. Consequently, the correspondence of parish officials as advocates is the subject of an extended discussion in the next section. In the meantime, the broad category of 'friends' to out-parish paupers is one that also deserves detailed attention given that it constitutes a third of all advocates' correspondence.

The notion of 'friendship' in eighteenth-century social relations has come under significant scrutiny, and as a result we now have a much more nuanced understanding of the breadth and fluidity of contemporary conceptualisations. ${ }^{31}$ Keith Snell and Steven King in particular have explored how "friendship" was understood in terms of the structural relationship between paupers and those they enlisted to assist them in the early-nineteenth century. Snell, for example, recognises that "[t]he term 'friends' had wide social usage and particular meanings in the eighteenth and nineteenth centuries," and "could include family in our senses today (fairly close relatives), but [also] encompassed a wider array of connected people as well," such as extended kinship networks and neighbours. ${ }^{32}$ King likewise notes the rhetorical value of friendship networks in the entitlement-building process and suggests that paupers explicitly sought to co-opt officials, employers and landlords as de facto "friends". ${ }^{33}$ Against this backdrop, it is possible in our corpus to discern a tri-partite hierarchy of advocate "friends": the friend as patron (including co-opted friends such as landlords); close acquaintances; and "good" friends, including relatives by blood or marriage. Their advocacy was for the most part willingly, and sometimes spontaneously, given. Both paupers and advocates themselves expected their testimony to influence the conduct of officials, sharing a sense of the malleability of the local state in the face of social power and philanthropic respectability.

In our underlying sample, the letters of "friends" appear at all stages in the chain of correspondence; but they are disproportionately represented as instigating letters, establishing 
the nature of the claim for relief and adding initial momentum. These letters tend to correspond to the highest level of friendship identified above, that of the friend as patron. Thus, J. Bellett wrote on behalf of Richard Lane, a pauper living at Honiton (Devon), but whose settlement was in Totnes (also Devon). Bellett stated that "the poor old Man has repeatedly called upon me" in order to solicit his assistance, and requested that his relief of two shillings (recently reduced from two shillings and sixpence) be substantially increased. ${ }^{34}$ In fact, this was not the first time Bellett had written on Lane's behalf: a year before he intervened in relation to a separate claim for clothing. Bellett's instigating letter is fairly typical of the form: he emphasised Lane's great age ( 80 years), the fact that he was in severe want and without any other form of support, and he went on to state, without undue embellishment, that even two shillings and sixpence "would, in my humble opinion, have the effect only of gradually starving a Man to death". ${ }^{35}$ Bellett wrote twice more (with what might be described as substituting letters) in relation to this particular claim over the space of four weeks. ${ }^{36}$ The first was a response to the fact that no reply had been received from the Totnes overseers to his initial approach, but the second makes it clear that, by then, he had been successful in securing an extra sixpence per week for the old man. ${ }^{37}$ As well as the earlier approach (in 1826, for clothing), two further letters dating from 1828 and 1829 survive, showing that Bellett acted as a "friend" and patron for Lane over an extended period, and as instigator in a number of different claims for relief. ${ }^{38}$

Bellett's correspondence is exemplary for a number of reasons. First, it is clear that he approached the Totnes overseers as at least their equal: in his instigating letter of 1827 he stated that " $[\mathrm{I}]$ trust that you will forthwith cause the additional sum of $6 \mathrm{~d}$. per week to be paid him". ${ }^{39}$ Secondly, there is no indication at any point that he had a prior personal connection with Lane, and it is therefore quite probable that he would not meet the definition of a "friend" to the old man in any modern, affectionate or egalitarian sense. Nonetheless, when prevailed upon to write on Lane's behalf he fulfilled a role well understood in the earlynineteenth century, undertaking an act of philanthropy convergent with his social standing and Christian duty. The model for this relationship has its distant roots in classical antiquity, as the philological debate over the precise meaning and usage of the Latin word amicus suggests. ${ }^{40}$ Yet, as that debate also demonstrates, there is genuine semantic disquiet over whether it is ever appropriate to describe the client-patron relationship in terms of "friendship"". ${ }^{41}$ Everett Ferguson explains that for pre-Christian civilization, " $\left.t\right]$ he interactions between patrons and clients and between members of a household represented the principal vertical relationships in society... [whereas] friendship was the ideal horizontal 
relationship". ${ }^{42}$ Such conclusions translate well to the many modern societies where individuals can enjoy a dyadic relationship based on mutual respect and a level of equality (friendship), or can enter into a patron-client relationship, which of itself implies a level of inequality and asymmetry between the two partners. In this framework "friend as patron" would be understood as a contradiction in terms. The problem with this normative interpretation for the student of pauper letters and epistolary advocates is that the evidence, from the early-nineteenth at least, is very clear: paupers consciously blurred the line between friendship and what we would more properly understand as a relationship of patronage.

The final point to note about Bellett's correspondence is that he consciously and deliberately triangulated the relationship between pauper (Lane), "friend" or patron (himself), and the parish officials of both the home and host parishes, despite the fact that there is no indication in his correspondence that he himself held any formal office at the time. In each of his letters, Bellett signed off by requesting that the Totnes overseer replied, not to him, but to the overseer of Honiton. In one of the later letters, he states that Lane "has made repeated applications to Mr. Turner, our Assistant Overseer,", but that Turner could not grant relief because he had "no answer to the several letters he [i.e. Turner] has written to you on the subject". ${ }^{43}$ It is clear that, in acting as a "friend" and advocate for Richard Lane, Bellett relied on the malleability of the local state in the face of social power and philanthropic respectability. Like the overseers with whom they often shared a social position, the advocate "friends" of the poor expected their testimony to influence parochial welfare policy. In the sense that their letters pointed to accumulated contribution to the community, the respectability of the pauper concerned or the extreme circumstances in which individuals found themselves, these advocates ranged across a linguistic and strategic register which had much in common with the paupers themselves. Yet these were letters which also claimed, exemplified and recorded yardsticks of deservingness as they were understood by host communities, a crucial service to the poor in a discretionary system of welfare.

Letters by close acquaintances and "good" friends (relationships founded on a longstanding familiarity and affection, in the modern sense) are relatively rare in the sample. Of the 252 letters from "friends" in the underlying corpus, only 64 could be said to have come from what we would now understand as acquaintances, and 29 of these were from one author. ${ }^{44}$ The sample is nonetheless important because it encapsulates a very different - more direct, impassioned and sometimes confrontational - advocacy to that employed by patrons. When Charles Taylor wrote an instigatory letter on the subject of William Tebbot from Northampton to the nearby village of Earl's Barton on 24 October 1830, he opened much as 
we might expect, noting that Tebbot "is in great distress and unable to support his family without your immediate assistance". Rather than then developing the detail of the case, however, Taylor asserted his deep personal knowledge of the family - "We have known him for some considerable length of time as an honest industrious man but unable from affliction in his family to provide for them" - and directed the overseer to act on the basis of his personal and informed testimony: "It is not necessary to give you any further information respecting him as I have no doubt you will provide for him to the extent of your ability." 45 Jonathan Ford was even more direct when he wrote an intervening letter on behalf of Sarah Robins from Derby (Derbyshire) to Earl's Barton on 1 December 1829. Robins was "in very great distress," because the Derby overseer had stopped paying an out-parish allowance, being unable to get recompense for this spending from Earl's Barton. Drawing on a long acquaintance with the family, Ford "would beg if you have any mercy in you that you would send the money immediately and not suffer a poor old woman of 74 years of age to die of starvation". Warming to his theme, Ford added "if the statement of Mr Moody's [the Derby overseer, who had been asked why he stopped paying] is correct I think you are very much to blame in not remitting the money when due ... if you do not think well to send the money the magistrates here shall be applied to". He trusted that "the magistrates will give the poor woman that full support that her case requires." ${ }^{46}$ For Taylor and Ford, patronage and familiarity intertwined to generate letters freighted with authority and assumption of action on the one hand and palpable emotion on the other. The expectation that practice under a discretionary welfare system would be fluid in the direction of paupers as well as ratepayers, is very clear.

Letters from "good" friends are similarly uncommon, and in fact only a handful from relatives on behalf of mothers, fathers, in-laws or children could be placed in this category. Such letters, almost invariably of the instigatory or substituting types, varied in tone, sentiment and intent on a spectrum between impassioned, almost breathless, through to detached reportage. They have in common a core narrative of tri-lateral partnership between pauper, friend and parish, one which simultaneously spoke to the basic conundrum of poor law practice - balancing the interests of paupers and ratepayers - and gave officials the moral cover needed to take a positive decision. Thus, the overseer of Oundle parish (Northamptonshire) noted in May 1836 that he "could not take upon myself the responsibility' of deciding on the future of 'the Lunatic Rippener". Having referred the matter to his friends and family "They have decided upon the course to be pursued and have made temporary arrangements for his removal" and in light of this positive action the overseer was 
emboldened to contract with Peckham Lunatic Asylum to pay for an extended stay in the hope of a cure. ${ }^{47}$ Similarly, William Brand both rehearsed an existing partnership and asked for its enhancement in relation to his (un-named) mother-in-law when he wrote from east London to Thrapston (Northamptonshire) in 1817. Having kept her with the help of a small parish allowance for the last two years, William Brand hoped "that during the winter the parish will be inclined to allow her more per week as her continued illness often requires the whole sum per week for medicine and my business being very dead I find it impossible to keep her and my family too." 48 This sort of partnership narrative, largely absent from other advocate letters, made the question of what to "do" with migrants rather less contentious than it might otherwise have been.

Overall, the preponderance of letters from well-connected or influential 'friends' as patrons further emphasises the sense that the Old Poor Law was pliable, a work in progress, and that the advocacy of the well-to-do was more than simply a strategic tool employed by the poor to gain competitive advantage. Those in this category who wrote on behalf of paupers - ministers of the church, 'respectable' rate payers, retired parish officials and professional men - readily engaged with overseers and vestries precisely because they wished to influence the nature and direction of relief, despite their occasional protestations to the contrary. Though they inevitably shared many of the moral precepts of those to whom they wrote, they did not suffer from a parish official's conflict of interests between the demands of paupers and ratepayers, and as a consequence they were able to fulfil their moral and Christian duty to the poor with a singularity of purpose. What is especially noteworthy is that so many chose to do so, and with such alacrity.

The final four identifiable categories of epistolary advocate - medical men, employers, landlords, and creditors - though important in themselves, are not as immediately relevant to this discussion and therefore invite only brief comment. Medical men could, on occasion, be found acting as "friends" to the poor in the sense that other respectable inhabitants did. However, the great majority of letters or notes from doctors and surgeons were cursory, and written in the form of certificates or brief comments attesting to a claimed illness or misfortune, often with a codicil that they had been asked to write by a pauper or official from a host parish. They generally take a form very similar to that of Charles Gilchrist of Sunbury, Surrey, who stated: "I certify that William Wonsford is unable to resume his occupation, but that he is in a convalescent state". ${ }^{49}$ As such, most correspondence from medical men falls into the category of interspersal. 
Similarly, the majority of letters from employers, landlords and creditors were of the interspersing kind. Most can be said to embody an element of self-interest, in the sense that they contained a request for the settlement of an unpaid bill, or for the temporary support of an incapacitated employee. However, this group also acted as "friends" to the poor employee or tenant on whose behalf they wrote, as for example when William Griffin wrote from Cheam (Surrey), to inform the parish of Shere (also Surrey) that his tenant, William Moore, owed him rent of $£ 3$. In so doing he made the case that Moore, "having a family of five Children, not one being able to work, [and] nor indeed is he scarcely able himself," was a deserving case for parish assistance. ${ }^{50}$ Similarly, James Clark wrote from Exeter to notify Sidmouth (Devon) that John Seaman had met with "a very severe accident while under my employ," and to request "a trifle to enable him to support himself until he is sufficiently recovered to work again". ${ }^{51}$ In a second letter, three weeks later, Seaman's employers wrote that he was still incapable of work, but they were keen to emphasise that he was "an object of pity", and "a worthy and honest labourer". 52 These instigating letters, whilst informed by some self-interest, expressed a similar rhetorical concern for the object of their attention to those of "friends" of the poor. They shared a similar linguistic register, and relied on the same yardsticks of deservingness. Insofar as they were part of a three-way negotiation for scarce resources - between a home parish, a pauper, and a landlord (for unpaid rent) or employer (for the temporary support of an incapacitated employee) - they were exceptional. Nonetheless, more often than not they were constructed as far more than simple threats to distrain a pauper or to send them home if the writer's claim went unheeded. They were highly complex pieces of writing in themselves; but more importantly, they were also clearly part of a complex system of negotiation, claim and counter-claim which involved all levels of local society. This complexity is revealed still further in our final typology of advocate's correspondence: that of overseers and other parish officers.

\section{The Overseer as Advocate}

The single largest group of epistolary advocates in the sample were officials (usually overseers) of the pauper's host parish, something that remains chronologically consistent across the corpus. ${ }^{53}$ The letters they sent were usually of the instigating, interspersing or intervening typologies. On the face of it, this concentration can be read as an inevitable outcome of the process of negotiating inter-parochial relations. Particularly in letters of 
instigation or interspersal, overseers pursued a number of objectives: to establish that a home parish wished to continue/begin a welfare arrangement; to request instructions on the amount of relief to be paid; to demand payment; to clarify payment mechanisms; or to advise settlement parishes of changes in pauper circumstances. There can be no doubt that overseer advocates in particular were frequently expedient in their support of a pauper's claim, aiming to save the costs of disputed settlement and removal or to prevent paupers who needed shortterm relief (for reasons of illness or temporary trade downturn), but who might be useful for the local labour market, from being removed to settlement parishes. ${ }^{54}$ The overseer of Hounslow, for instance, wrote to John Young's parish (Farnham, Surrey), to say "I think it may save you much trouble $\&$ expence if you will send him some casual relief". ${ }^{55}$ Robert Brickwood, overseer of St. Germans (Cornwall), instigated correspondence and wrote three times to Totnes in support of Robert Hellman and his family. In his first letter, Brickwood used considerable rhetorical force to impress upon the Totnes overseers that Hellman "is ill [and] not able to follow his employment, and reduced to necessity," and that he "implores your assistance, [as] his wife also labours under an ailment". In his next letter, he used a more pragmatic approach, stating that Hellman "is still unable to follow his employment," but that "I have no doubt...after receiving some temporary relief" he would be able to get a job. Having finally received notice that Totnes refused any relief for Hellman, Brickwood pointedly noted that removal would have to ensue but that "I [had] trusted you would not have put us to this Expence". ${ }^{56}$ The corpus is replete with similar examples: the overseer of Skipton (Yorkshire) noted that a pauper "is very thankfull' for his relief, and 'I hope [he] will get work soon and trouble you no more;" and Robert Stark, overseer of Torquay (Devon), wrote that if Nicholas Weeker from Sidmouth (Devon) was given a pound in relief, "by the time it is expended he may be able to work again". 57

Nonetheless, to suggest that it was solely expediency that motivated overseer advocates is to simplify an extremely complex relationship. Officials did not just report facts or seek action. Rather, their letters often included appeals or information in support of a pauper's application for relief, and employed a rhetoric which implied a genuine concern for paupers under their charge. It was common - more common than a simple expediency motivation would perhaps warrant - for officials to write multiple times for the same pauper, and for them to move to letters from the intervening typology at times of crisis. More detailed consideration of this class of narratives reveals much about the malleability of local state power, shared understandings of how paupers could and should navigate a discretionary 
welfare system, and how officials understood their competing obligations to the poor and the communities that they represented.

Thus, when Robert Brickwood (see above) noted that Robert Hellman and his family "implores your assistance" he may have been simply repeating or rendering a conversation with the pauper, or he may have been hinting at his own feelings given the severe case of sickness involved. There seems be little doubt, though, that the overseer of Wateringbury (Kent) was moved by compassion when he wrote an instigating letter to Farnham (Surrey) about the plight of William Collings and his wife, who had "applyed to me to state their present situation to you". "The man is become so very inform [sic] thro' an astma on his Lungs," he wrote, and:

he is incapacitated for any work whatever and has been obliged wholly to give up his situation as Journeyman Blacksmith to Mr Ellis - His wife is also very ill \& unable to do anything - They appear to have a very great wish not to be sent home to your Parish \& earnestly request you would have the Kindness to allow them your regular Parish pay on such occasions, allowing them to receive it here. $^{58}$

Of course, the proposed arrangement would have benefited Wateringbury. As the host parish it would most likely have been forced to apply to the magistrates for a suspended order of removal, disadvantaging them practically and financially. ${ }^{59}$ Nonetheless, the overseer's rendering and then embellishment of the case suggest genuine concern for Collings's welfare, a view which is further strengthened by the fact that he autonomously authorized the payment of $£ 11$ s. for the burial of Collings's wife in July 1832. While he later made attempts to recover the sum from Farnham, the overseer must have known at the time that there was a strong chance of this charge falling on his own ratepayers. ${ }^{60}$ Examples like this are numerous in the letters of overseer advocates, and their frequency points to the existence of a deeply ingrained framework of individual philanthropy sitting alongside the conduct of local offices of state.

The fact that officials wrote across the typological spectrum from instigation to intervention both confirms that humanitarian sentiment and personal philanthropic sensibilities were at work and suggests that officials in settlement parishes did not have, and were not expected to have, unrestrained power. To return to our last example, the Collingses occupied a privileged space under the Old Poor Law because their infirmity was directly due 
to being both aged and sick (in the wife's case, sick unto death). ${ }^{61}$ As the editors of a recent volume on the sick poor in Europe have noted, even amongst the aged poor "relief in whatever form was invariably tied into progressive disability and inability to labour because of physical or mental weakness". ${ }^{62}$ In other words, the evidence suggests that age or sickness, physical disability or mental incapacity were not in themselves enough to guarantee an entitlement to relief; but on the other hand, when combined they were likely to form a very compelling case indeed, and more especially if supported by an official. Against this backdrop it is notable that the majority of letters written by overseer advocates relate to paupers who were aged, infirm, sick, or, more likely, a combination of the three. Many were about the continuation of relief rather than just its initial granting, such as Overseer Bostock's letter to the home parish of Hannah Parkinson, wherein he writes: "I understand that she formerly received $1 / 6$ per week from you, and that that the allowance was discontinued about seven weeks ago". ${ }^{63}$ Bostock continued:

she is 50 years of age and consequently incapable of much bodily exertion - she used to go out washing, but has been obliged to give it up from inability ... Under these circumstances I hope you will consider to allow her the 1/6 as before, which I really think is as little as you should do for her. ${ }^{64}$

Through letters like these, officials worked collectively to balance of the interests of parochial taxpayers and welfare recipients within the framework of a system which notionally gave parishes the power to eschew such considerations. They are simultaneously a record of the malleability of the local state and a mechanism by which such malleability could be created. Because they were frequently solicited by applicants, and often constructed in collaboration (William Collings and his wife, "applyed to me to state their present situation to you"), they formed an important navigation point for paupers whose rights were heavily circumscribed. In this sense, they were essentially public documents by which paupers both informed the process of their own relief, and gained greater understanding of the mechanisms by which that relief was (and could be) negotiated.

Although exceptional in its longevity, the correspondence relating to Widow Elizabeth Atack (or Attick) is a vivid example of the way in which overseers came to actively advocate on behalf of the poor. She first appeared in correspondence between the overseers of Dawlish (Devon) and her home parish of Sandal Magna (West Yorkshire), in $1791 .{ }^{65} \mathrm{At}$ that stage, it is clear that she was already in receipt of a regular allowance. In 1792, the 
Dawlish overseer wrote an instigating letter to Sandal Magna stating that "Widdow Attatack $[$ sic $]$ has been poorly agood while and was it not for $\mathrm{y}^{\mathrm{e}}$ Charity of good neighbours Must have more than you allow her" ${ }^{66}$ He added that "I can assure it for truth she has had many [entirely discretionary] Little helpe from $\mathrm{y}^{\mathrm{c}}$ parish in Close and other Little necessaries," and closed his letter by stating that "She is a very Clean industeris woman". ${ }^{67}$ Thereafter, she continued to be relieved by Sandal Magna at a distance for at least another four decades, a relationship which generated almost 50 pieces of surviving correspondence. All of the letters were written by overseers or other parish officials, and they cover the entire rhetorical register from perfunctory and pragmatic to impassioned pleas on her behalf.

A questionnaire sent out by Sandal Magna in 1835 allows us to establish some basic facts about Atack herself: in that year she was aged 77 (so was 33 when the surviving correspondence began), had been relieved for 50 years, had been blind since she was 24 years old, and had just the one child (a son) who remained unmarried with no children and was earning 8s. a week as a "Day labering Man" ${ }^{68}$ We also know, from the content of the correspondence over the years, that both Atack and her son had regular bouts of sickness and infirmity, that she lived for most of the period covered by the letters in Dawlish, and that she moved in with her son at Kenton (Devon) in 1834 before moving to Teignmouth (Devon) in 1837. ${ }^{69}$ In short, Widow Atack fulfilled the profile of a most deserving pauper throughout her long association with the parish. These, at least, are the verifiable details on which her parish would have based its decision to relieve her for so long, so far from home.

Yet despite the strength of her claim Atack's entitlement to relief required constant reaffirmation over the years. The overseers of her home parish regularly queried her circumstances and often attempted to make adjustments to her relief on the basis of real or assumed changes in her situation. For example, when Atack's son was bound out as an apprentice, the vestry of Sandal Magna made it clear that "[t]hey expect W Attack will do with less pay than when she had the Boy to keep," adding that "they think she might be employd in something to bring her a little money," despite the fact that her host parish had consistently maintained she was incapable of any work at all. ${ }^{70}$ This particular letter did not draw an immediate response from the Dawlish overseer (at least, not one that remains in the archive) but over time those serving as overseer consistently took Atack's part in negotiations with her settlement parish. In 1807, for example, Francis Tripe wrote in an intervening letter that "she cannot support [herself] on the pay and she has had nothing more than her regular pay for four Years past," adding "she never troubles the Parish for any Clothing never since the pay was first remittd". ${ }^{71}$ This testimony of an ability to "make do" must be read alongside 
earlier letters such as that of 1792 (dealt with above) in which we find such clothing needs were met by small discretionary gifts from the parish and from friends and neighbours. Widow Atack was, in other words, and despite her migratory status, a respected member of both her neighbourhood and the parochial community represented by the overseer.

By 1813, Overseer Firth was writing to acknowledge the receipt of Atack's allowance, but also requested that it be increased, adding that "as an Overseer of the Poor of Dawlish [her pay] is not adequate for her Sustenance at this time". He offered the settlement parish an independent benchmark of sufficiency based upon his long experience of office, encouraging them to moderate their practice in the knowledge of policy elsewhere. At the end of this letter Firth sought further to emphasise Widow Atack's respectability and embeddedness in her host community, stating that "she could not have remained on that sum," had not her friend assisted her "who has a large Family". 72 Towards the end of the correspondence the vestry of Sandal Magna took the drastic step of reducing her weekly relief from $4 \mathrm{~s}$. to $2 \mathrm{~s} 6 \mathrm{~d}$. 'in consideration of Provisions being so low, and that her Son might do something for her'. ${ }^{73}$ This seems to have been a step too far for the Dawlish overseer, who brought all the rhetorical force at his disposal to bear on the settlement parish:

As you have redused her pay to $2 / 6 \mathrm{pr}$ week I decline paying any longer as her friends inform me she...cannot keep her in the state she is in which I am informed you know having sent a person to see her_ She now intend to apply to the parish officers of Kenton for a relief and an Order of Removal which no doubt will be suspended[.] It appears to me likely you will have moor to pay than you usually use to...as it is impossibly [sic] she can provide all necesserys for her at 2/6 $\mathrm{Pr}$ week. $^{74}$

This robust response, in effect withdrawing from the informal network relationship that kept the Old Poor Law working efficiently, is significant. A brother overseer had unilaterally reduced an allowance below the subsistence level applied by the host parish and done so in the face of clear evidence of need - Sandal Magna had sent someone to inspect the Widow, after all. In so doing the settlement parish had transgressed an implied duty to balance the different parochial interests and the language of advocacy used by overseer Ferris in this situation - he considered it impossible for Atack to provide all of the necessities of life on her allowance, even with the assistance of her friends - was both powerful and direct. Unfortunately, even these apparently heartfelt appeals failed to weaken the resolve of the 
Sandal Magna vestry. They refused to increase the widow's relief. As a result, the final piece of intervening correspondence from the overseer of Kenton, in 1837, shows her "Lying in a deplorable state" at the home of her son, who was "now scarcely able to maintain himself". Faced with such suffering the overseer sought to enlist the services of others among Kenton's most authoritative and respectable inhabitants on Atack's behalf. Appended to his letter are a certificate from William Collyns, Member of the Royal College of Surgeons, who stated that "Blind Widow Attack, is in a very deplorable state," and a note from Jonathon Thompson, Curate of Kenton, who also confirmed that "Widow attack is in a deplorable state of wretchedness". 75

These sorts of instigating, interspersing and intervening letters form the core of our corpus of narratives from officials. While it is clear that such people sometimes acted solely in the interests of the parish and office, this kind of correspondence has more subtle lessons. Passionate advocacy was common, and most overseer advocates at least offered embellishment or opinion, suggesting an important combination of humanitarian and philanthropic principles in the office of the overseer. The correspondence relating to Widow Attack suggests that the local state could be fractured and fractious on the subject of welfare entitlements, but the very fact that the overseer letters were written in the first place points to the potential malleability of local power. Indeed, the palpable outrage in the closing letter by the Kenton overseer suggests an absolute expectation of accommodation between brother officers who had the responsibility for balancing the interests of paupers and payers at the heart of the Old Poor Law. Moreover, both advocates letters and these occasional disputes were important in establishing yardsticks of behaviour, rhetoric and status in a discretionary welfare system. These were public documents involving contact with the family or individual and no doubt feedback, giving the poor themselves some fixed navigation points around what their host communities found acceptable in welfare terms. The action of the Dawlish overseer in involving other members of the community in support of his advocacy - in effect creating a powerful backdrop of respectability - was a public as well as a symbolic act and one repeated throughout the corpus. It simultaneously points to a significant network of smallscale individual philanthropy and provides an absolute sense for both in- and out-parish paupers of what the local office-holders thought was a sufficient sum for providing 'necessaries'. 


\section{Conclusion}

Much of the literature on pauper narratives has seen direct pauper agency as a major influence on who got what relief under the Old Poor Law. Our material, however, demonstrates both that advocate letters were the most common form of communication in efforts to establish or maintain entitlement, and that such letters were important in shaping a basic set of expectations about the kinds of people that ought rightly to be relieved in a discretionary welfare system. This is not to downplay the importance of pauper voices or to question the sense that the poor had more agency under the Old Poor Law than was allowed in early poor law historiography. It is, however, to suggest that the place of such agency and the very real complexity of the operation of the Old Poor Law at local level can only be understood when pauper narratives are placed alongside other communicative avenues of the sort explored in this article. After all, many advocates got involved in relief negotiations without even knowing the pauper concerned and sometimes without being asked. And many of them went well beyond what paupers might have requested in their own narratives, offering a persistent and insistent commentary on the proper duty of parishes to their periodically or chronically poor citizens.

This is perhaps surprising. The very presence of the out-parish poor raised, as we have suggested, universal questions about what to "do" with migrants and how to tension their requirements against an accumulated contribution to host and settlement communities. Advocate letters suggest that the answers to these questions are not straightforward. For migrants of long residence or family connection we see a spectrum of attitudes and emotions, ranging from tolerance through to warm acceptance and active support for people whose contribution to either host or settlement community can be mapped and weighed. Yet advocates also supported the transient or unconnected poor with equal vigour, and while we can recognise Keith Snell's framework of local xenophobia, the striking thing about our dataset is the powerful intersection of custom, philanthropic duty and Christian obligation coalescing in advocate letters which overrode the simple label "migrant". This applies, perhaps most notably, to those serving in official roles as well as others who might be regarded as the traditional "respectable parish other" such as clergymen. ${ }^{76}$

For the poor seeking to navigate a discretionary welfare system, we have argued that advocate letters provided important yardsticks. By and large these were publically constructed, executed and reported document and they help to explain the emergence of a 
shared linguistic register of eligibility between paupers, officials and advocates that others have also traced. ${ }^{77}$ The fact that officials and others in our corpus forcefully asserted the minimum standards of welfare that they would expect to see applied by overseers of host parishes provided a very powerful sense indeed, for both paupers and those receiving the letters, of normative levels of relief. ${ }^{78}$ More than this, advocate letters in general suggest that the local state was, was supposed to be, and was supposed to be seen to be, malleable and contestable. Many writers simply assumed that their word would be enough to prompt officials to (re)consider the balance between their duties to ratepayers and those to poor citizens. In plenty of cases it was. Where letters went unanswered or inaction ensued, advocate voices could become insistent, multiple and layered into wider processes such as calling upon magistrates to compel malleability. While nowhere stated explicitly, a close reading of the corpus suggests very clearly that inaction was seen as questioning the respectability, status and philanthropic credentials of writers. For officials such inaction had the added dimension that a host parish's failing to respond weakened the basic glue that kept the Old Poor Law functioning as a more or less coherent national system of welfare.

It is clear that during the period covered by this article the Old Poor Law was overtaken by a crisis of political confidence that resulted in the formation of the New Poor Law in 1834. This notion of crisis was clearly shared by some officials and elites in rural England, where poverty was seen to be increasingly endemic and threatening. Yet, we find little evidence, either in this corpus or the wider parochial archives on which it rests, of dwindling sympathy for the claims of the poor and migrant poor in the public imagination. Advocacy - pauper and independent - on a spectrum from restrained and respectful to passionate and sometimes angry usually brought or modified a response, something which speaks strongly to Lynn Hollen Lees sense of interlocking social obligations between paupers and payers even as the political lifeblood of the Old Poor Law seeped away from the 1790s. 


\section{Endnotes}

${ }^{1}$ For an overview of the English and Welsh system see Lynn Hollen Lees, The Solidarities of Strangers: The English Poor Laws and the People 1700-1948 (Cambridge, 1998), passim.

${ }^{2}$ Lori Charlesworth, Welfare's Forgotten Past: A Socio-Legal History of the Poor Law (Oxford, 2010), 93 and Lori Charlesworth, "Big Society, Legal Structures, Poor Law and the Myth of a Voluntary Society," in Armine Ishkanian and Simon Szreter, eds., The Big Society Debate: A new Agenda for Social Welfare? (Cheltenham, 2012), 52-4. For a succinct critique of this view see Steven King's review of Welfare's Forgotten Past in Rural History 22 (2011): 271-3.

${ }^{3}$ On the settlement laws and removal, see Keith Snell, Parish and Belonging: Community, Identity and Welfare in England and Wales, 1700-1950 (Cambridge, 2006), passim.

${ }^{4}$ Steven King, "Negotiating the law of poor relief in England 1800-1840," History 96 (2011): 410-35; Peter King, "The summary courts and social relations in eighteenth-century England," Past and Present 183 (2004): 124-72.

5 Gwenda Morgan and Peter Rushton, "The magistrate, the community and the maintenance of an orderly society in eighteenth century England," Historical Research 76 (2003): 54-77, pp.74.

6 Susannah Ottoway, The Decline of Life: Old Age in Eighteenth Century England (Cambridge, 2004).

${ }^{7}$ Brian Barber, Memorandum Book of Richard Tilburn and John Daniell: Overseers of the Poor for the Township of Doncaster (Doncaster, 2009), 24 and 26. Our italics.

${ }^{8}$ Steven King, "'It is Impossible for Our Vestry to Judge His Case Into Perfection from Here': Managing the distance dimensions of poor relief, 1800-40," Rural History 16 (2005): 161-189, pp.165.

9 Joanna Innes, Steven King and Anne Winter, "Settlement and Belonging in Europe, 15001930s: Structures, Negotiations and Experiences," in Steven King and Anne Winter, eds., Migration, Settlement and Belonging in Europe, 1500s-1930s (Oxford, 2013), 1-28, passim.

${ }^{10}$ See Thomas Sokoll, Essex Pauper Letters, 1731-1837 (Oxford, 2001).

${ }^{11}$ Alannah Tomkins recently evoked this potential when she wrote of pauper letters that '[t]he English poor...do not require us to give them a voice; they possessed voices of their own. They merely require us to turn up the volume'. Alannah Tomkins, "'I mak Bould to Wrigt': First-Person Narratives in the History of Poverty in England, c.1750-1900,' History Compass, 9 (2011): 370.

${ }^{12}$ Hollen Lees, Solidarities of Strangers, 11.

${ }^{13}$ Of course being outside the parish also gave the pauper some bargaining currencies. Parishes might avoid the cost of settlement examination and removal or be able to pay paupers less than would be the case if they were to come 'home'. Many letters reference a willingness to return to the settlement parish for this reason.

${ }^{14}$ This is well explored in Peter Jones, "'I cannot keep my place without being deascent': Pauper Letters, Parish Clothing and Pragmatism in the South of England, 1750-1830," Rural History 20 (2009), 31-49.

${ }^{15}$ Steven King, "'Stop this overwhelming torment of destiny': Negotiating financial aid at times of sickness under the English Old Poor Law, 1800-1840," Bulletin of the History of Medicine 79 (2005): 228-60.

${ }^{16}$ For example, see Thomas Sokoll, "Writing for Relief: Rhetoric in English Pauper Letters," in Andreas Gestrich, Steven King and Lutz Raphael, eds., Being Poor in Modern Europe:

Historical Perspectives 1800-1940 (Bern, 2006), 91-112.

${ }^{17}$ Berkshire Record Office, D/P139/18/5/4, 'Letter'. Steven King, Thomas Nutt and Alannah Tomkins, Narratives of the Poor in Eighteenth Century Britain (London, 2006), 284-5. 
${ }^{18}$ On the classic pauper letter, see James Stephen Taylor, "A different kind of Speenhamland: Nonresident relief in the Industrial Revolution," Journal of British Studies 30 (1991): 183208, and Sokoll, Essex, passim.

${ }^{19}$ There is evidence from vestry minutes that in-parish paupers also used advocates, particularly kin and neighbours, but the usage was different in scale, periodicity and intent for the out-parish poor.

${ }^{20}$ Hollen Lees, Solidarities of Strangers, 11.

${ }^{21}$ On this issue and the wider 'crisis of the Old Poor Law' from the 1790s, see Hollen Lees, Solidarities of Strangers, 82-111.

${ }^{22}$ Jones, "II cannot keep my place", 31.

${ }^{23}$ Thomas Sokoll, "Negotiating a Living: Essex Pauper Letters from London, 1800-1834," International Review of Social History 45 (2000): 31, 42-46; Steven King, ';I Fear You Will Think Me Too Presumtuous in My Demands but Necessity Has No Law': Clothing in English Pauper Letters, 1800-1834," International Review of Social History 54 (2009): 216, 220, 234; Tomkins, 'I mak Bould to Wrigt", 365.

${ }^{24}$ Sokoll, "Negotiating a Living", 29.

${ }^{25}$ The reasons for this sort of chronological concentration center around increased literacy, the ramping up of regional postal systems, the development of non-cash payment mechanisms and the increased availability of small change from the 1780s.

${ }^{26}$ Notwithstanding that it had more vibrant towns, industrial specialisms and commercial agriculture than is often allowed. See Pamela Sharpe, Population and Society in an East Devon Parish: Reproducing Colyton 1540-1840 (Exeter, 2002), passim.

${ }^{27}$ The total for Surrey includes 18 letters which came to light for historic Surrey parishes in the collections of the London Metropolitan Archive.

${ }^{28}$ Judith Hill, "Poverty, unrest and response in Surrey, 1815-1834”, Unpublished PhD, University of Roehampton, 2006 and Steven King, "Reconstructing lives: The poor, the poor law and welfare in rural industrial communities," Social History 22 (1997): 318-38, point to short durations of relief in Surrey and Lancashire respectively.

${ }^{29}$ Northamptonshire Record Office (hereafter NRO), Peterborough St John Letters (bundle 244), Letter 3.

${ }^{30}$ This is also true of pauper letters themselves, though see Steven King's analysis of an unrelated sample: “The particular claims of a woman and a mother': Gender, belonging and rights to medical relief in England 1800-1840s," in Astri Andresen, Tore Grǿnle, William Hubbard, Teemu Rymin and Sven A. Skålevåg, eds., Citizens, Courtrooms, Crossings (Bergen, 2008), 21-38.

${ }^{31}$ See, for example, Naomi Tadmor, Family and Friends in Eighteenth Century England: Household, Kinship and Patronage (Cambridge, 2000) and Naomi Tadmor, "Friends and Neighbours in Early Modern England: Biblical Translations and Social Norms," in Laura Gowing, Michael Hunter and Miri Rubin, eds., Love, Friendship and Faith in Europe, 13001800 (Basingstoke, 2005), 150-176. For a purely theoretical discussion of 'friendship', see Andrew Silver, "Friendship in Commercial Society: Eighteenth-Century Social Theory and Modern Sociology," American Journal of Sociology 95 (1990): 1474-1504. Most recently, Barbara Caine, ed., Friendship: A History (London, 2014).

${ }^{32}$ Keith Snell, 'Belonging and community: understandings of 'home' and 'friends' among the English poor, 1750-1850,“ Economic History Review 65 (2012): 1-25, pp.4.

${ }^{33}$ Steven King, "Friendship, Kinship and Belonging in the Letters of Urban Paupers 18001840," Historical Social Research 33 (2008): 263 and 271.

${ }^{34}$ Devon Record Office (hereafter, DRO), 1579A/24/117/3, J. Bellett to the overseers of Totnes, 3 March 1827. 
${ }^{35} \mathrm{Ibid}$.

${ }^{36}$ In this instance, substituting for correspondence written by the pauper himself, or by anyone else on his behalf, none of which exists in the archive.

${ }^{37}$ DRO, 1579A/24/117/26 \& 27, J. Bellett to the overseers of Totnes, 13 and 17 April 1827.

${ }^{38}$ DRO, 1579A/24/118/2 \& 1, J. Bellett to the overseers of Totnes, 31 January 1828 and 18 February 1829.

${ }^{39} \mathrm{DRO}, 1579 \mathrm{~A} / 24 / 117 / 3$.

${ }^{40}$ See, for example, David Konstan, "Patrons and Friends," Classical Philology 90 (1995): 328-42.

${ }^{41}$ Ibid., pp.328-9.

${ }^{42}$ Everett Ferguson, Origins of Early Christianity (Third ed., Grand Rapids, Michigan, 2003), 67-8.

${ }^{43}$ DRO, 1579A/24/118/2.

${ }^{44}$ Thomas Wilkinson of Knottingley, West Yorkshire, on behalf of his friend, Francis

Sawyer, written over a nine year period between 1823 and 1832. See West Yorkshire Record

Office (hereafter WYRO), WDP20/9/3/10/1,6,7,8,11,15,19 \& 23; WYRO,

WDP20/9/3/11/2,3,4,6,27,28,31 \& 32; WYRO, WDP20/9/3/12/1,2,8,10,11,13,17,24,27,28,30

\& 30; WYRO, WDP20/9/3/13/3, Thomas Wilkinson to the overseers of Sandal Magna on

behalf of Francis Sawyer, 9 March 1823 to 20 December 1832.

${ }^{45}$ NRO, Earls Barton letters $110 \mathrm{p} / 138 / 15$

${ }^{46} \mathrm{NRO}$, Earls Barton letters 110p/138/9

${ }^{47} \mathrm{NRO}, 249 \mathrm{p} / 216$ Oundle Letter book, Letter 119.

${ }^{48}$ NRO, 194p Thrapston Letter Book, Letter 44.

${ }^{49}$ Surrey Record Office (hereafter SRO), 1956/1/11/8, Charles Gilchrist to unknown parish official, 10 November 1818.

${ }^{50}$ SRO, SHER/28/8/2, William Griffin to the Overseers of Shere, 11 February 1828.

${ }^{51}$ DRO, 1855A/PO40to44/4, J. Clark to the Overseers of Sidmouth, 15 September 1823.

${ }^{52}$ DRO, 1855A/PO40to44/5, E. Clark to the Overseers of Sidmouth, 8 October 1823.

${ }^{53}$ There was a discrepancy between regions, with West Yorkshire recording the highest proportion of parish officers acting as advocates (43 per cent of advocate letters), and Westminster recording the lowest ( 7 per cent). This issue has been explored above but if we exclude Westminster none of the other counties records a figure of less than 30 per cent of advocates' letters written by this group.

${ }^{54}$ King, "'It Is Impossible to Judge"”: 164.

${ }^{55}$ SRO, 1505/Box37/F1/24, Peter Boughton to Farnham, 19 September 1831.

${ }^{56}$ DRO, 1579A/24/118/13-15, Robert Brickwood to Totness, December 1829 to February 1830. The problem for St. Germans was that the cost of sending a pauper back to their parish of settlement was incurred by the removing parish. See Norma Landau, "The Laws of Settlement and the Surveillance of Immigration in Eighteenth-century Kent," Continuity and Change 3 (1988), 412 and Keith Snell, "Settlement, Poor Law and the Rural Historian: New Approaches and Opportunities," Rural History 3 (1992): 152.

${ }^{57}$ WYRO, WDP20/9/3/11/11, John Holdsworth to Skipton, 12 August 1826; DRO, 1855A/PO40to44/3, John Bridgeman and Robert Stark to Sidmouth, 29 July 1823.

${ }^{58}$ SRO, 1505/Box37/F1/30, Thomas Smith to Farnham, 6 December 1831.

${ }^{59}$ After 1795 , a host parish was legally obliged to relieve a pauper who was too sick or infirm to be removed to his or her parish of settlement, and was therefore forced to apply to a magistrate for a "suspended order of removal" which could only be enforced following the recovery of the pauper. This was a costly and time-consuming process which many parishes sought to avoid. See Snell, Parish and Belonging, 143. 
${ }^{60} \mathrm{SRO}, 1505 /$ Box37/F1/39, Thomas Smith to Farnham, 9 October 1832 . The work of Hurren and King suggests that the overseer could just have left the body unburied and written to the overseer of the settlement parish for authority to bury 'according to custom'. See Elizabeth Hurren and Steven King, "Begging for a burial: Death and the poor law in eighteenth and nineteenth century England," Social History 30 (2005): 321-341. We found few examples of this practice.

${ }^{61}$ We know they were aged because Collings himself alludes to it in his own letters to Farnham. SRO, 1505/Box37/F1/33, William Collings to Farnham, 19 December 1831; SRO, 1505/Box37/F2/25, William Collings to Farnham, 15 June 1833.

${ }^{62}$ Andreas Gestrich, Elizabeth Hurren and Steven King, "Narratives of poverty and sickness in Europe 1780-1938: Sources, methods and experiences"" in Andreas Gestrich, Elizabeth Hurren and Steven King, eds., Poverty and Sickness in Modern Europe: Narratives of the Sick Poor, 1780-1938 (London, 2012), 1-34, pp.3.

${ }^{63}$ WYRO, WDP20/9/3/12/15, J. Bostock to Asst. Overseer (name and parish unknown), 9 August 1827.

${ }^{64}$ Ibid.

${ }^{65}$ WYRO, WDP20/9/3/5/7, Richard Whidborne to Sandal Magna, 19 February 1791.

${ }^{66}$ This sense of neighbours helping to relieve the burden on the parish is common and again speaks to deeply ingrained individual philanthropy at the parochial level.

${ }^{67}$ WYRO, WDP20/9/3/5/8, Richard Whidborne to Sandal Magna, 5 May 1792. Our italics. The postscript was entirely discretionary, though it also speaks to one of the ways in which eligibility could be claimed by paupers themselves.

${ }^{68}$ WYRO, WDP20/9/3/19/5, John Firth to Sandal Magna, n.d. (1835).

${ }^{69}$ Ibid.; WYRO, WDP20/9/3/8/15, W. Hoare to Sandal Magna, 15 March 1818; WYRO, WDP20/9/3/9/13, John Firth to Sandal Magna, 19 June 1821; WYRO, WDP20/9/3/13/10, R. Ferris to Sandal Magna, 13 April 1828.

${ }^{70}$ WYRO, WDP20/9/3/5/7, Unnamed correspondent to Sandal Magna, n.d.

${ }^{71}$ WYRO, WDP20/9/3/6/7, Francis Tripe to Sandal Magna, 30 March 1807.

${ }^{72}$ WYRO, WDP20/9/3/7/22, John Firth to Sandal Magna, 13 April 1813.

${ }^{73}$ WYRO, WDP20/9/19/4, John Firth to Dawlish, 10 July 1835.

${ }^{74}$ WYRO, WDP20/9/19/4, R. Ferris to Sandal Magna, 4 July 1835.

${ }^{75}$ WYRO, WDP20/9/21/5, J. Southwood to Sandal Magna, 11 March 1837.

${ }^{76}$ Keith Snell, "The culture of local xenophobia," Social History 28 (2003): 1-30.

${ }^{77}$ On shared linguistic registers, see Steven King and Alison Stringer, "II have once more taken the Leberty to say as you well know': The development of rhetoric in the letters of the English, Welsh and Scottish sick and poor 1780s-1830s,", in Gestrich, Hurren and King, Poverty and Sickness, 69-92.

${ }^{78}$ By way of example, an unnamed correspondent from Stamford (Lincolnshire) wrote to Paul Large, overseer of Oundle in Northamptonshire on 30 May 1833 to note his actions in relation to 'your [sick] Parishoner Prentice'. He had acted 'as if he had belonged to us' and this involved paying for lodgings, commissioning doctors and nurses, paying for food and giving cash relief, 'Indeed [I] did exactly the same as we should have done for our Own Paupers in the same disease'. This was a powerful assertion of normative standards and is not unusual in the corpus. See NRO, 249p/216 Oundle Letter book, Letter 14. 